\title{
FIZIOTERAPIJA BOLESNIKA LIJEČENIH TRANSPLANTACIJOM KRVOTVORNIH MATIČNIH STANICA
}

\begin{abstract}
Sažetak
Fizioterapija ima svoje mjesto u gotovo svim granama medicine, pa i kao dio liječenja bolesnika s malignim bolestima. $\mathrm{U}$ ovome se radu razmatra uloga fizioterapije u bolesnika s hematološkim malignim bolestima liječenih transplantacijom krvotvornih matičnih stanica. Prikazan je tijek liječenja transplantacijom krvotvornih matičnih stanica od pripreme za transplantaciju do razdoblja nakon transplantacije te problemi i komplikacije koje se pritom javljaju. Liječenje transplantacijom praćeno je nizom komplikacija kao što su promjene na muskoloskeletnom sustavu te na kardiovaskularnom i respiratornom sustavu. Posebno je izražen problem akutne i kronične reakcije transplantata protiv primatelja (graft versus host disease, GvHD). Način liječenja kojem je bolesnik podvrgnut i sve komplikacije rezultiraju raznolikim ozbiljnim tjelesnim promjenama koje utječu na fizičko stanje i kvalitetu života bolesnika, pa i na krajnji ishod liječenja. Fizioterapija tih bolesnika iznimno je važna u svakom trenutku liječenja, a njezini učinci na kvalitetu života bolesnika, smanjenje komplikacija i konačni ishod liječenja relativno su slabo istraženi. Zbog specifičnoga stanja i komplikacija nakon transplantacije hematološkim je bolesnicima potreban jedinstven i složen pristup u fizioterapijskim procedurama. Međutim, ne postoje jasna uputstva i protokoli koje bi fizioterapeuti nužno slijedili i provodili u bolesnika liječenih transplantacijom krvotvornih matičnih stanica. Opisana su dosadašnja iskustva i navedeni mogući pristupi fizioterapiji tih bolesnika.

Ključne riječi: hematološki bolesnik, transplantacija krvotvornih matičnih stanica, kvaliteta života, fizioterapijska intervencija
\end{abstract}

\section{Uvod}

Transplantacija koštane srži (TKS), odnosno krvotvornih matičnih stanica (TKMS) terapijska je metoda kojom se manje vrijedne i bolesne krvotvorne matične stanice zamjenjuju zdravima (Labar, 2008: 1091). Postupak TKMS-a razvijao se tijekom

\footnotetext{
* Martina Ilić, univ. bacc. fizioterapije

* prof. dr. sc. Damir Nemet, dr. med., redoviti profesor u trajnom zvanju, Libertas međunarodno sveučilište, dnemet@mef.hr
} 
više desetljeća, počevši od sedamdesetih godina prošloga stoljeća. Prvenstveno je riječ o liječenju hematoloških malignih bolesti, akutnih i kroničnih leukemija, ali i teških nemalignih bolesti, kao što su aplastična anemija ili teški poremećaji imunoga sustava. Prvenstveni je cilj transplantacije omogućavanje intenzivne kemoterapije s ciljem eliminacije zloćudnoga tumora, a da se pritom uništeni krvotvorni sustav nadomjesti novim matičnim stanicama. Također, i sama nova koštana srž djeluje protiv tumora. Kao izvor matičnih stanica mogu poslužiti koštana srž, periferna krv te krv iz pupkovine. Liječenje u ranim fazama bolesti i dok je tumor u manjem obliku (remisija bolesti) pruža veću vjerojatnost izliječenja bolesti. Ako u obitelji postoji srodnik koji je s bolesnikom podudaran u glavnom kompleksu tkivne podudarnosti, tj. u HLA sustavu, tada će biti moguće provesti liječenje alogenom transplantacijom od srodnika. Danas je sve učestalija primjena liječenja transplantacijom alogene koštane srži od HLA - podudarnoga, ali nesrodnoga davatelja kao i primjena transplantacije vlastitih, autolognih krvotvornih matičnih stanica (Labar, 2008: 1091).

Transplantacijom alogenih matičnih stanica postižu se vrlo dobri rezultati u liječenju akutne leukemije i drugih malignih hematoloških bolesti. Liječenje bolesnika $s$ akutnom leukemijom u ranoj fazi dok je tumorska masa malena postiže najpovoljniji terapijski učinak, a uspjeh ovisi i o vrsti leukemije. Oko 60 \% bolesnika koji su liječeni u prvoj fazi remisije bolesti žive više od pet godina (Labar, 2008: 1091). Slični su i rezultati liječenja, mada nešto skromniji, kod bolesnika s akutnom limfocitnom leukemijom. Petogodišnje preživljenje iznosi 50 \% kod pacijenata liječenih od akutne limfocitne leukemije u prvoj remisiji (Labar, 2008: 1091). Zbog značajnog broja izliječenih bolesnika koji imaju posljedice liječenja, od velike je važnosti skrb o bolesnicima u periodu nakon transplantacije.

TKMS je izuzetno složena i zahtjevna metoda liječenja praćena nizom komplikacija i nuspojava kod bolesnika, kako zbog primjene intenzivne kemoterapije i radioterapije tako i zbog oštećenja imuniteta i imunoloških reakcija između tkiva domaćina i presađenoga tkiva (reakcija transplantata protiv primatelja, engl. graft-versus-host disease - GvHD). Zbog toga može ostaviti posljedice na fizičko i psihičko stanje bolesnika (Labar, 2008: 1091). Sama maligna bolest i način liječenja povezani su sa širokim spektrom teških fizičkih i psiholoških promjena zbog čega treba pridavati sve veću važnost i pozornost i fizikalnoj medicini i rehabilitaciji kako bi se upotpunila i poboljšala cjelokupna skrb za bolesnike. I u slučajevima kada je liječenje uspješno, bolesnik će doživjeti osjetan pad tjelesne aktivnosti za vrijeme i nakon TKMS-a (Steinberg, 2015: 2447).

Kod bolesnika s malignim hematološkim bolestima koji su podvrgnuti kemoterapiji javlja se smanjenje tjelesnih funkcija, mišićne snage i izdržljivosti. Liječenjem transplantacijom u bolesnika se još više smanjuju mišićna snaga i izdržljivost. Nadalje, svi bolesnici koji su bili podvrgnuti liječenju transplantacijom borave u izolaciji radi 
sprečavanja neželjenih infekcija zbog čega se javlja značajan pad tjelesne aktivnosti tijekom boravka u izolaciji (Steinberg, 2015: 2447).

Fizikalna terapija treba biti sveobuhvatna za svakoga bolesnika te se temeljiti na poznavanju postupka liječenja, evaulaciji bolesnika i multidiscipliranom liječenju. Tjelovježba koju vodi fizioterapeut klinički će biti učinkovita te će pomoći kao dio ukupnog terapijskog pristupa u tih bolesnika. Sve veći broj istraživanja o primjeni fizikalne terapije u bolesnika liječenih TKMS-om ukazuje na potrebu da se posebna pozornost posveti simptomima i problemima bolesnika kao što su umor, nedostatak fizičke aktivnosti i kasne komplikacije na lokomotornom i kardiorespiratornom sustavu. Zbog toga treba posebno raditi na razvoju vježbanja i poboljšanju rehabilitacije tih bolesnika, kao i na razvoju jasnih protokola fizioterapijskih procedura prilagođenih tim bolesnicima (Bergenthal, 2014).

Cilj je ovoga rada pokazati da je fizioterapija kao mlada struka premalo razvijena u liječenju hematoloških bolesnika. Rad također ima cilj potaknuti fizioterapeutsku struku u istraživanju protokola za jasnu rehabilitaciju hematoloških bolesnika te istaknuti potrebu da hematološki bolesnik treba tijekom i nakon transplantacije fizioterapeutsku skrb kako bi vratio prijašnje stanje i bio sposoban za svakodnevni život.

\section{Promjene u fizičkom stanju i komplikacije transplantacije}

Glavna karakteristika posttransplantacijskoga stanja jest izrazit pad imuniteta, tj. smanjena otpornost organizma na infekcije. Ovisno o komplikacijama nakon transplantacije i prisutnosti GvHD-a, oporavak imuniteta može biti izrazito produžen, a u slučaju jače kronične reakcije GvHD-a deficit imuniteta može trajati i godinama. Prvi cilj nakon transplantacije jest hematološki oporavak, tj. uspostavljanje normalnog broja i funkcije krvnih stanica, a zatim i oporavak imunoga sustava te sprečavanje reakcije transplantata protiv primatelja (GvHD) (Labar, 2008: 1091).

Česte komplikacije su različite vrste infekcija (virusnih, bakterijskih i gljivičnih), zatim GvHD te rane i kasne toksičke komplikacije vezane uz primjenu intenzivne kemoterapije i/ili zračenja. Smrtnost kod liječenja kreće se od 15 do 30 \% (Labar, 2008: 1091). Akutni oblik GvHD-a manifestirat će se u prvih 100 dana nakon liječenja. Incidencija akutnoga oblika iznosi 40 do 60 \% (Labar, 2008: 1091).

Komplikacije vezane uz GvHD klinički se manifestiraju promjenama na koži, jetri i probavnom sustavu. Na dlanovima, tabanima, licu, a potom i na postraničnim dijelovima trupa javljaju se kožne promjene u obliku makulopapuloznoga osipa. U probavnom sustavu dolazi do obilne proljevaste stolice. U težim oblicima GvHD-a može se razviti i ileus (Labar, 2008: 1091).

Incidencija kroničnoga oblika GvHD-a iznosi 25 do 50 \%. Kronični GvHD izgleda kao autoimuna bolest i traje mjesecima, pa i godinama te značajno utječe na 
fizičko stanje i kvalitetu života bolesnika. Kožne promjene manifestiraju se slikom poput lichen planusa. U uznapredovaloj fazi karakteristični su znakovi za sklerodermu (koža koja je fibrozirana, neelastična i tanka). Kronični GvHD jetre pokazuje sliku kroničnoga aktivnog hepatitisa. Također se pojavljuju promjene u obliku smanjenja sekrecije sline i suza (kserostomija i kseroftalmija s fotofobijom). Patološke promjene javljaju se i na drugim organima, na plućima se manifestiraju kao bronchiolitis obliterans (Labar, 2008: 1091).

Liječenje akutnog GvHD-a obavlja se imunosupresivnim lijekovima s ciljem ublažavanja imunološke reakcije davateljevih limfocita na organizam bolesnika primatelja. Ti lijekovi također imaju neka neželjena djelovanja poput steroidne miopatije, avaskularne nekroze kosti i osteoporoze.

\subsection{Promjene lokomotornoga sustava}

\subsubsection{Steroidna miopatija}

Steroidna miopatija definira se kao kao „podmukao početak proksimalne slabosti mišića i atrofije s većim zahvaćanjem donjih i gornjih udova" (Bhavaraju-Sank i Jackson, 2014). Steroidna je miopatija podijeljena na endogenu i egzogenu. Egzogena steroidna miopatija je učestalija, incidencija joj iznosi 2,4 \% - $21 \%$. Egzogena steroidna miopatija uzrokovana je lijekovima, a endogena je vezana za spol (žene više obolijevaju) ili dob (više od 80) (Bhavaraju-Sank i Jackson, 2014).

Pojavnost steroidne miopatije ovisit će o tome kolike su doza i učestalost uzimanja kortikosteroida. Steroidna se miopatija znatno češće javlja u bolesnika s akutnim ili kroničnim GvHD-om kao posljedica kortikosteroidne terapije radi suprimiranja reakcije imunološkoga sustava. Žene su podložnije oblijevanju od steroidne miopatije od muškaraca. Steroidna miopatija ima izuzetan utjecaj na mišićna vlakna tipa II. Mišićna vlakna tipa II služe nam za kratku eksplozivnu snagu, u a svakodnevnom životu za penjanje po stepenicama i odlazak na toalet (podizanje iz niskoga čučnja). Kao rezultat propadanja mišićnih vlakana bolesnici bivaju izloženi velikom riziku od pada, a time dolazi do gubitka neovisnosti bolesnika. Steroidna miopatija najčešće zahvaća mišiće ekstenzore koljena (quadriceps femoris), a bolesnici imaju slab stisak ruke i oslabljenu respiratornu muskulaturu (Bhavaraju-Sank i Jackson, 2014).

\subsubsection{Avaskularna nekroza kosti}

Avaskularna nekroza predstavlja infarkt kosti, nastaje radi prekida ili poremećaja dotoka krvi u kosti. Avaskularna nekroza može nastati uz neku poznatu bolest (leukemija, limfomi, metastatski tumori kostiju) ili može biti nepoznatoga uzroka, tj. idiopatska. Često nastaje kao posljedica liječenja glukokortikoidima (Mohammed et al., 2019: 127). Avaskularna nekroza manifestira se bolovima u kostima ili zglobovima te 
dovodi do smanjena opsega pokreta. Kod osoba liječenih TKMS-om avaskularna se nekroza najčešće manifestira kao bol u kuku.

Fizioterapeuti moraju odigrati iznimno važnu ulogu u bolesnika kod kojih je nastupila avaskularna nekroza s ciljem jačanja mišića koji okružuju zahvaćeno mjesto kako bi se smanjila bol. Jačanjem mišića i smanjenjem boli dolazi do poboljšanja opsega pokreta te poboljšanja pacijentove kvalitete života. Pasivne se tehnike također preporučuju u fizioterapijskoj intervenciji, a od njh se koriste ekstrakorpornalni udarni val, elektroterapije te miofascialne tehnike (Mohammed et al., 2019: 127).

\subsubsection{Osteopenija i osteoporoza}

Osteoporoza je jedna od najučestalijih metaboličkih bolesti te predstavlja izniman javnozdravstveni problem. Najčešća mjesta prijeloma kod osteoporoze su kukovi, kralješci i donji dio podlaktice. Osteopenija se definira kao pojam smanjene koštane gustoće koja je uzrokovana gubitkom koštane mase (Bobinac, 2010). Iako je dokazano da vježbanje dovodi do poboljšanja i povećanja koštane mase, nije svejedno kakve će se vježbe provoditi. Na zdravlje kostiju značajan utjecaj imaju vježbe antigravitacijskoga tipa te aerobne vježbe (skakanje, trčanje). Plivanje se, kao aerobna vježba, ne preporučuje zbog toga što nema kontinuiranoga tjelesnog opterećenja koštanoga sustava. Brzo hodanje je sportski oblik rekreacije, terapijskoga vježbanja kojim najjednostavnije postižemo ciljanu aktivnost za održavanje tjelesne kondicije, psihičke funkcije i mišićnoga tonusa. Vježbe jačanja kod bolesnika s osteoporozom ili osteopenijom obuhvaćaju vježbe izometričkoga oblika, s manualnim otporom uz opterećenje utezima radi povećanja aktivnosti osteoblasta čime dolazi do porasta i gustoće koštane mase. Vježbe istezanja odnose se na pokrete u kojima se mišići istežu iznad standardne fiziološke dužine koju posjeduju u stanju mirovanja. Vježbe istezanja imaju cilj poboljšanje bolesnikove pokretljivosti i elastičnosti mišića. Uz vježbanje ne treba zanemariti dovoljan unos kalcija i vitamina $D$ te liječenje bolesti štitnjače ako postoje (Bobinac, 2010).

\subsection{Kardiorespiratorna disfunkcija i fizioterapijska intervencija}

Promjene koje se javljaju na kardiovaskularnom sustavu u hematoloških bolesnika posljedica su više mogućih toksičnih djelovanja kemoterapije i zračenja. Najpoznatije je oštećenje srčanog mišića citostaticima, sposebno iz grupe antraciklina (adriamicin, daunorubicin) koji mogu uzrokovati ozbiljnu toksičnu kardiomiopariju sa slabljenjem srčane funkcije. Te posljedice mogu se ispoljiti i nakon dužeg vremena od provedene terapije citostaticima (Čustović et al., 1995: 673).

Također i radioterapija provedena u području prsnog koša uzrokuje potencijalno ozbiljne posljedice na srčenu i plućnu funkciju. Posljedice radioterapije su moguća pojava perikarditisa s izljevom ili bez njega, konstrikcijski perikarditis i kronična konstrikcija perikarda, na plućima fibroza i kronični emfizem. Rijetka komplikacija 
na srcu je endomiokardna fibroza koja se očituje nespecifičnim promjenama na EKGu, disfunkcijom papilarnih mišića i restriktivnom kardiomiopatijom. Javit će se kod bolesnika koji su primili dozu zračenja veću od $3500 \mathrm{R}$, a prvi simptomi bolesti mogu se očitovati i 5 do 15 godina nakon terapije zračenjem (Čustović et al., 1995: 673).

Oslabljen aerobni kapacitet iznimno je česta pojava u bolesnika nakon transplantacije KMS-om što pridonosi smanjenju tjelesne aktivnosti. Osim toga, relativno česta komplikacija u bolesnika koji nakon transplantacije razviju GvHD je sindrom bronhiolitis obliterans (BOS). BOS je karakteriziran kašljem, šištanjem i simptomima dispneje s progresivnom respiratornom insuficijencijom. Uloga je fizioterapeuta provesti respiratornu rehabilitaciju kao prevenciju. Mjerenjem plućnoga volumena i brzine protoka procjenjuju se dišne bolesti, a mjerenje se izvodi spirometrom. Procjena mišićne snage respiratornih mišića obavlja se pomoću manualnog mišićnog testa (MMT). Cilj je fizikalne terapije provesti vježbe disanja radi poboljšanja opće funkcije disanja i smanjenja subjektivnoga osjećaja dispneje.

\subsubsection{Fizioterapeutska procjena kod bolesnika s kardiorespiratornom disfunkcijom}

U tih bolesnika fizioterapijska procjena uključije anamnezu i fizikalni pregled, procjenu funkcije respiratornih mišića (uočavanje mišićne aktivnosti prilikom respiracija), procjenu aktivnosti i kvalitete života, testove plućne funkcije (spirometrija) te prisutnost drugih simptoma (depresija, tjeskoba, bol).

Fizikalni pregled uključuje:

- određivanje stupnja dispneje (ocjenom od 0 do 4; 0 - bez simptoma, 1 - blaga zaduha koju primjećuje pacijent, 2 - blaga zaduha koju primjećuje ispitivač, 3 - umjerena zaduha, moguća je aktivnost, 4 - teža zaduha, bolesnik treba prestati s aktivnošću)

- mjerenje zasićenosti periferije kisikom (SpO2) (normalna vrijednost SpO2 je 95 - 98 \%) i broj respiracija (normalan broj respiracija iznosi 10 do 20 u minuti)

- mjerenje vršnoga ekspiratornog protoka (PEF) (procjenjuje se ograničenje protoka zraka)

- mjerenje krvnoga tlaka, pulsa

- šestominutni test

- askulutacija (krepitacije, diskontinuirani zvuk nalik „škripanju poput snijega”, zvižduci)

- procjena bolesnikove posture (odnos anteroposteriornoga i transverzalnoga dijametra prsnoga koša)

- prisutnost/odsustvo boli tijekom disanja

- respiracija (bradipneja, tahipneja, apneja, produženi ekspirij - brzi inspirij, hiperventilacija, dispneja). 
Najbitnija komponenta za svako uspješno izvođenje vježbi je pravilno disanje. Vježbe za disanje uključuju udisaj na nos te aktivaciju dijafragme i izdisaj na usta. Vježbe disanja iznimno su prilagodljive na širokom spektru bolesnika te se mogu izvoditi u ležećem, sjedećem i stojećem položaju.

\subsection{Umor kao posljedica raka}

Umor (engl. cancer related fatigue, CRF) je jedan od najčešćih simptoma kod bolesnika koji boluju od raka. Umor se najčešće definira kao postojani, subjektivni osjećaj tjelesne i/ili kognitivne iscrpljenosti povezane s rakom ili njegovim liječenjem koje nije proporcionalno s nedavnom aktivnošću (Steinberg, 2015: 2447). Umor je jedan od najčešćih ukazanih simptoma koji remete svakodnevnu kvalitetu života. Najčešće je prvi na listi po negativnom utjecaju, a iza njega su bol, depresija i mučnine.

Etiologija CRF-a nije u potpunosti jasna, ali potencijalni čimbenici koji mogu izazvati umor su kemoterapija i zračenje, sama maligna bolest, hormonalne promjene, stres, loša prehrana, neaktivnost, genetska ranjivost te drugi medicinski problemi.

Zapravo, CRF se negativno odražava na cjelokupnu čovjekovu tjelesnu funkciju, radnu funkciju, socijalnu integraciju, obiteljsku funkciju, obrazovanje, raspoloženje, kognitivne funkcije te cjelokupnu aktivnost u zajednici (Steinberg, 2015: 2447). Umor se također javlja u bolesnika liječenih TKMS-om. Na slici 1 prikazani su brojni uzroci umora u bolesnika s rakom (Mortimer, 2010: 1331). U studiji Gielissena i suradnika (Steinberg, 2015: 2447) procijenjeno je da se umor koji je povezan s rakom javlja u $35 \%$ ispitanika koji su imali transplantaciju krvotvornih matičnih stanica prije 15 godina, a u 41 \% ispitanika koji su imali transplantaciju krvotvornih matičnih stanica u razdoblju nakon jedne do pet godina od transplantacije. Autori su došli do zaključka da lijekovi, hemoglobin i umor nemaju međusobne povezanosti.

Slika 1. Brojni čimbenici koji utječu na pojavu umora u bolesnika s rakom ().

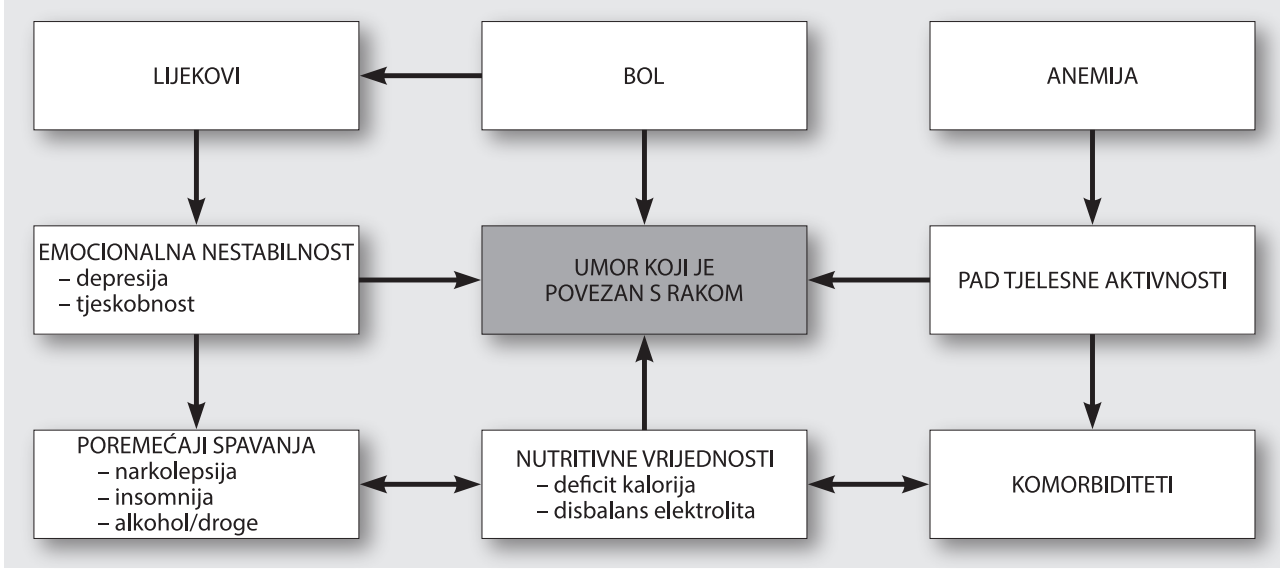

Izvor: Mortimer, 2010: 1331 
Nedvojbeno je potvrđeno da vježbanje smanjuje CRF. Vjeruje se da postoje mehanizmi vježbanja koji imaju snažno protuupalno djelovanje, koji se mogu sumirati u nekoliko točaka (Steinberg, 2015: 2447).

1. Viscelarna će se masnoća (loša mast) smanjivati tijekom vježbanja. Porastom viscelarne masti povećava se aktivnost upalnih citokina, TNF-a, IL-6 i leptina. Redovitim vježbanjem smanjuju se viscelarna masnoća, opseg struka i, najznačajnije, aktivnost upalnih citokina.

2. Vježbanjem dolazi do oslobađanja IL-6. Oslobađenjem IL-6 doći će do protuupalnoga djelovanja jer je IL-6 protuupalni citokin. IL-6 tijekom vježbanja dovodi do nagloga porasta protuupalnih citokina kao što su anatgonisti IL-10 i IL-1.

3. Tijekom vježbanja nadbubrežna žlijezda izlučuje hormone kortizol, epinefrin i norepinefrin koji izazivaju snažno protuupalno djelovanje.

4. Vježbanjem će se fenotip masnih stanica promijeniti i doći će do smanjenja upale.

Protuupalni učinci koji nastaju tijekom vježbanja mogu objasniti zašto vježbanje povoljno utječe na umor koji nastaje djelovanjem raka, no potrebna su još brojna istraživanja koja će pratiti vrstu, učestalost, trajanje i intenzitet vježbanja, posebno u osoba liječenih TKMS-om. U tablici 1 sumarno su prikazani učinci liječenja transplantacijom krvotvornih matičnih stanica na bolesnika (Steinberg, 2015: 2447).

Tablica 1. Moguće komplikacije i posljedice liječenja transplantacijom krvotvornih matičnih stanica

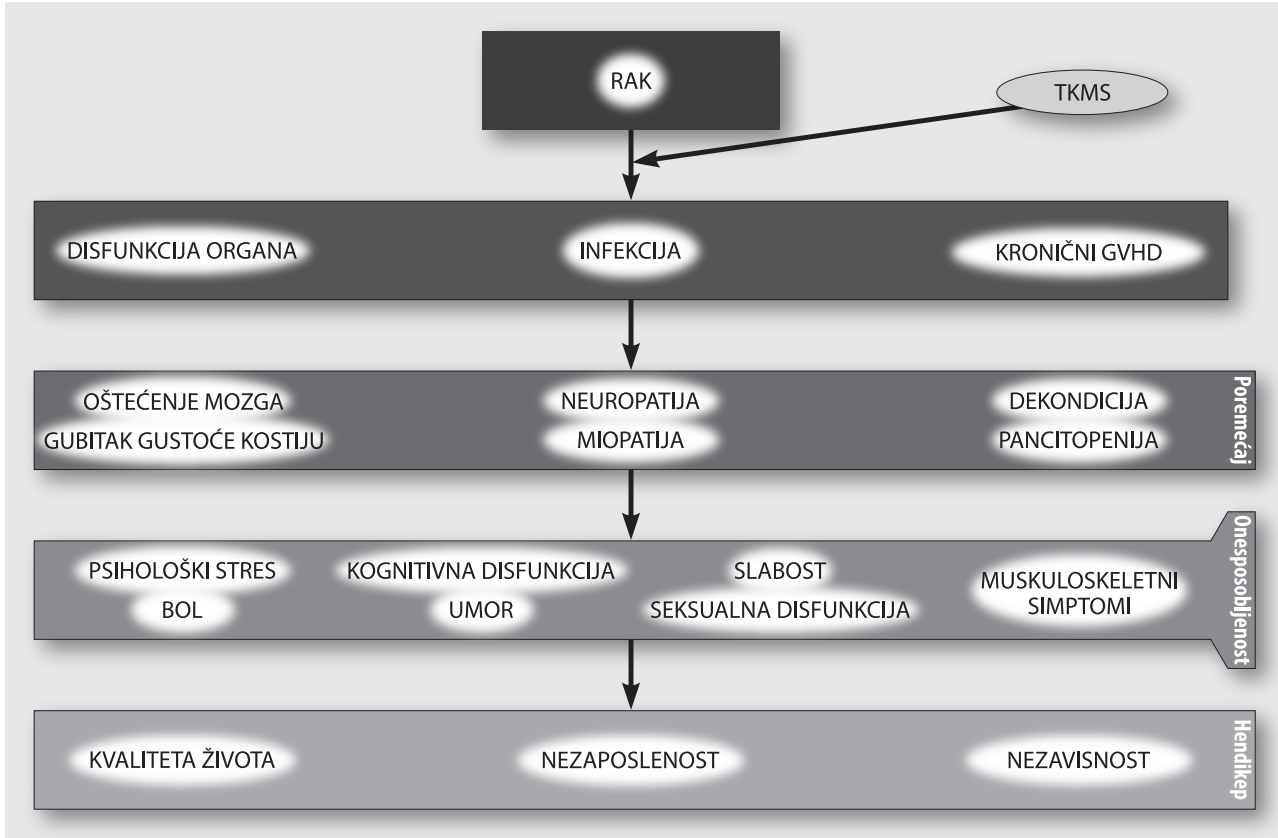

Izvor: Steinberg, 2015: 2447) 


\section{Istraživanja učinka fizioterapije na bolesnike liječene transplantacijom krvotvornih matičnih stanica}

U literaturi postoji relativno malo studija koje su izučavale učinak fizioterapijskih postupaka tijekom i nakon liječenja bolesnika liječenih TKMS-om. Veći dio opisanih rezultata proizlazi iz opservacijskih, nekontroliranih, nerandomiziranih studija. Ovdje ćemo navesti rezultate samo nekoliko randomiziranih usporednih studija bolesnika u kojih su primjenjivani odgovarajući fizioterapijski postupci.

Provedene intervencije uglavnom su se provodile tijekom faze hospitalizacije, ali i u ambulantnom liječenju, a neke čak i u kućnom liječenju. U najvećem broju studija provođene su aerobne vježbe / vježbe izdržljivosti.

U studiji Baumana et al. (2010: 355) sudjelovala su ukupno 64 bolesnika. Kontrolna je skupina činila 32 bolesnika, a eksperimentalna također 32 bolesnika. Prosječna starost bolesnika koji su sudjelovali u kontrolnoj skupini iznosila je 44,1 godinu, a u eksperimentalnoj grupi 49,4 godine. U eksperimentalnoj su grupi sudjelovali bolesnici sa sljedećim dijagnozama: deset bolesnika s akutnom mijeloičnom leukemijom (AML), šest sa akutnom limfoblastičnom leukemijom (ALL), dva s kroničnom mijeloičnom leukemijom (KML), četiri s multiplim mijelomom (MM), pet s neHodgkinovim limfomom / kroničnom limfocitnom leukemijom (NHL/KLL), četiri s mijelodisplatičnim sindromom (MDS) i jedan bolesnik sa solidnim tumorom, a u kontrolnoj grupi: 15 AML, tri ALL, jedan KML, pet MM, tri NHL/KLL, dva MDS, dva solidna tumora, jedan imunodeficijencija.

Program za eksperimentalnu grupu započinjao je šest dana prije početka transplantacije krvotvornim matičnim stanicama. Korišten je bicikl ergometar 10 do 20 minuta dva puta na dan, a dva puta dnevno u trajanju od 20 minuta eksperimentalna je grupa provodila vježbe za održavanje mobilnosti u svakodnevnom životu. Vježbe su temeljene na istezanju, koračanju i hodanju. Kontrolna je grupa započinjala vježbanje jedan dan prije transplantacije krvotvornim matičnim stanicama. Vježbe kontrolne skupine sastojale su se od aktivne i pasivne mobilizacije (gimnastika, masaža, vježbe ekstenzije, kordinacijski trening) s niskim intenzitetom u trajanju pet dana u tjednu. Obje skupine (kontrolna i eksperimentalna) završavale su proces rehabilitacije dan prije otpuštanja iz bolnice. Rezutat je istraživanja sljedeći: ukupan pad izdržljivosti zabilježen je u objema skupinima, dok je u kontrolnoj skupini zabilježen pad u kvaliteti života i mišićnoj snazi. Eksperimentalna je skupina zabilježila porast kvalitete života (Baumann, 2010: 355).

U studiji Colemana et al. (2003: 410) sudjelovala su ukupno 24 bolesnika. Eksperimentalnu je skupinu činilo 14 bolesnika, a kontrolnu skupinu deset ispitanika. Prosječna starost bolesnika koji su sudjelovali u eksperimentalnoj skupini iznosi 55 godina, a u kontrolnoj skupini također. Sudionici koji su sudjelovali u eksperimentalnoj 
i kontrolnoj grupi bili su bolesnici s novootkrivenim mutiplim mijelomom, a stadij bolesti nije poznat. Program za eksperimentalnu skupinu počinjao je 10 tjedana prije prve transplantacije krvotvornih matičnih stanica. Vježbe eksperimentalne grupe provodile su se u kućnim uvjetima. Bolesnici su kući provodili vježbe trčanja, vožnje biciklom ili hodanje i trening snage s otporom te vježbe istezanja (po mogućnosti s trakom). Tijekom boravka u bolnici eksperimentalna je skupina imala program koji se sastojao od hodanja, vježbi snaženja, istezanja te vježbi izdržljivosti. Kontrolnoj se skupini preporučala aktivnost. Preporuka je bila da bolesnici hodaju 20 minuta svaki dan minimalno tri tjedna. Ukupan rezultat istraživanja je porast tjelesne mase u eksperimentalnoj skupini, a pad tjelesne mase u kontrolnoj skupini (Coleman, 2003: 410).

U studiji DeFora et al. (2007: 948) sudjelovalo je ukupno 100 bolesnika. Kontrolnu je skupinu činilo 49 bolesnika, a eksperimentalnu grupu 51 bolesnik. Prosječna starost oboljelih u eksperimentalnoj skupini bila je 46 godina, a u kontrolnoj skupini 49 godina. I u eksperimentalnoj i u kontrolnoj skupini sudjelovali su bolesnici s raznim hematološkim oboljenjima i različitim stadijima bolesti. Eksperimentalna je skupina započinjala vježbanje u bolnici gdje su dobili zadatak da hodaju dva puta na dan po 15 minuta na traci za trčanje. Trake za trčanje bile su postavljene u bolesničkim sobama. Nakon otpusta bolesnici su dobili upute kako provoditi rehabilitaciju u kući. Sudionike su zamolili da hodaju 30 minuta dnevno. Intenzitet hodanja nije bio strogo zadan već su trebali hodati intenzitetom kojim će se osjećati ugodno, a ako dođe do smetnji poput vrtoglavice ili osjećaja nelagode, trebali su prekinuti vježbanje i savjetovati se s liječnikom o daljnjem nastavku rehabilitacije. Kontrolna skupina nije provodila nikakve vježbe, već im je savjetovana umjerena aktivnost. Imala je mogućnost u bolnici zatražiti traku za trčanje.

Rezultat studije prema Karnofsky ljestvici jest sljedeći: značajan pad tjelesnih sposobnosti zabilježen je u objema skupinama, u eksperimentalnoj i kontrolnoj skupini. Značajan porast emocionalnoga i tjelesnoga blagostanja zabilježen je u objema skupinama (DeFor, 2007: 948). Rezultati tih studija sumarno su prikazani u tablici 2.

Sistemskim pregledom Cochrane baze podataka uočeno da vježbe imaju itekakav utjecaj kod osoba s CRF-om, posebno tijekom kemoterapija i zračenja. Vježbe su osjetno pridonijele poboljšanju kvalitete života, boljem raspoloženju, zdravlju kostiju, boljem snu, poboljšanju funkcionalnih sposobnosti te poboljšanju metabolizma (Bergenthal, 2014). Vježbanje bolesnika liječenih TKMS-om dovelo je do fizioloških i psiholoških poboljšanja. Vježbanje je pridonijelo smanjenju umora i smanjenju mišičnoskeletnih problema. Potrebno je dodatno istražiti optimalan tip, intenzitet i vrijeme vježbanja kako bi došlo do poboljšanja u bolesnika liječenih TKMS-om.

U sažetku, rani počeci fizioterapijske intervencije u TKMS-u pokazali su da rana tjelesna aktivnost i rana mobilizacija imaju pozitivne učinke na bolest. Pozitivan utjecaj zamijećen je u aerobnom vježbanju. Aerobno vježbanje smanjilo je gubitak 


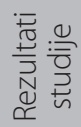

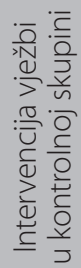

!uıdnys foujolzuoy

/loupezuəu!ıәdsyə

n ex!usə|oq

qop euग्रə]!sold

eu!dnys eu|oגzuoy /еиретuәш!ıәуу - I!! pnis n ey!usəjoq !oגg

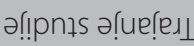

ว!!
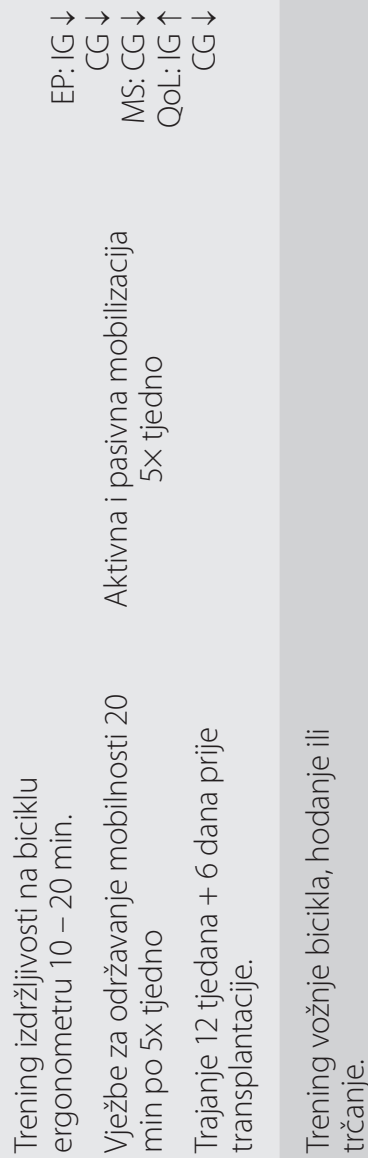



守导

余芒

$\underset{\pi}{\pi} \underset{\pi}{\mathbb{I}} \stackrel{11}{z}$

余宅
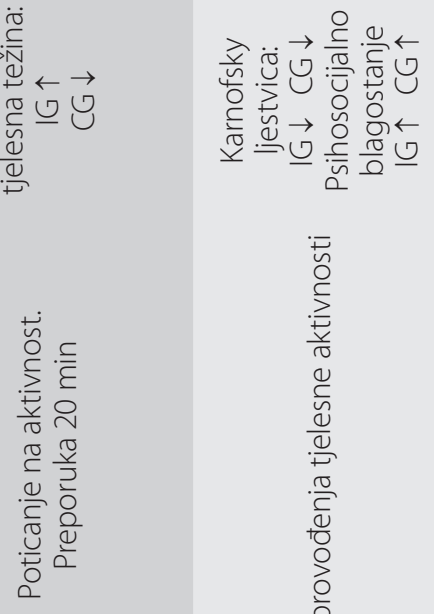

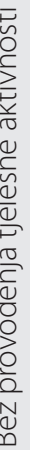

סे

or $\frac{0}{2}: \frac{\sqrt{0}}{\frac{\pi}{2}}$

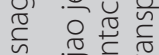

or $\frac{\pi}{5}$

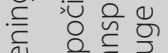

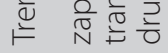

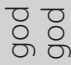

约织

完

8

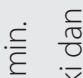

: $\frac{2}{0}$

당

잉 $\sum_{\pi}^{\infty}: \frac{0}{3}$

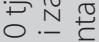

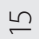

$\circ)$

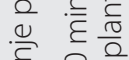

등 을

들

๖ ปे

य)

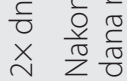

80
080
08

아 아

啇

สิด

$\sum z$

各 +.ं

월ํํㅇ

ஜ் 용 용

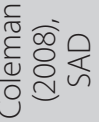

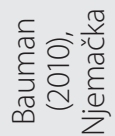

홍유워 
funkcionalnosti, vidno je došlo do smanjenja proljeva te smanjenja prijema u bolnicu nakon otpuštanja. Aerobno je vježbanje poboljšalo kardiovaskularne funkcije. Uz poboljšanje kardiovaskularne kondicije došlo je i do smanjenja umora i stresa. Individualizirano je dolazilo do poboljšanja mišićne snage.

\section{Fizioterapijska procjena kod bolesnika liječenog transplantacijom matičnih stanica}

Svaka hospitalizirana osoba koja čeka transplantaciju krvotvornih matičnih stanica trebala bi proći kroz sustav fizioterapijske procjene. Jedan od glavnih razloga primjene sustava fizioterapijske procjene je praćenje funkcionalnoga kapaciteta bolesnika, a također i promjena na muskoloskeletnom sustavu (MSK).

\subsection{Subjektivna evaulacija}

U nastavku navodimo što bi subjektivna evaulacija uz uobičajenu procjenu trebala obuhvatiti (Steinberg, 2015: 2447).

1. Postojeće stanje koje se odnosi na MSK

Planiranje transplantacije te rehabilitacije nakon transplantacije s težištem na već poznatoj funkcionalnoj nesposobnosti te raspoznavanju komplikacija koje su nastale poslije same transplantacije, kao i to pod kojim su uvjetima nastale.

2. Zanimanje/interesi

Uvidjeti pacijentove potrebe/želje u vezi s povratkom na posao. Tijekom fizikalne terapije treba stavljati naglasak na osposobljavanje osobe kako bi mogla izvršavati aktivnosti svakodnevnoga života te također omogućiti djelomičan ili potpun povratak na posao.

3. Lijekovi

Fizioterapeut bi trebao dobiti podatke od bolesnika i liječnika koje lijekove pacijent uzima te koje je lijekove uzimao. Također, valja procijeniti što bi od toga moglo izazvati potencijalne nuspojave koje bi mogle nastati tijekom oporavka te produžiti pacijentov boravak u bolnici.

\subsection{Objektivna procjena}

Kad god je moguće, potrebno je napraviti procjenu pacijenta prije i nakon TKMS-a. Sve dobivene podatke potrebno je zabilježiti u sustav ili u fizioterapijski karton. Kod pacijenata koji nisu u mogućnosti proći cjelokupnu procjenu cilj je napraviti procjenu jednog gornjeg i jednog donjeg ekstremiteta te popuniti upitnik o kvaliteti života.

Procjena bi se trebala sastojati od sljedećih postupaka (Mohammed et al., 2019: 127): 
1. opseg pokreta gornjih i donjih ekstremiteta (goniometar)

2. dinamometrija šake, dinamometrija pincentnoga hvata

3. manualni mišićni test

4. ustani - sjedni test (30 s)

5. šestominutni test hoda

6. EORTC-QLQ-C3O upitnik

7. LEFS

8. individualni upitnici za ruku, rame, šaku (Quick DASH).

\subsection{Bolnički protokol za fizikalnu terapiju}

Bolesnici koji imaju fizikalnu procjenu prije samog TKMS-a mogu krenuti u individualnu fizioterapijsku proceduru koja će se temeljiti na povećavanju snage i izdržljivosti, kardiovaskularnom treningu i treningu propriocepcije. Sam plan i tijek vježbanja fizioterapeut bi trebao donijeti u suglasnosti s liječnikom. Vježbe se nikako ne bi smjele davati generalizirano i šablonski svim bolesnicima nego bi za svakoga pacijenta trebao biti individualno osmišljen plan vježbanja i izvođenje vježbi prema općem stanju bolesnika.

\section{Program rehabilitacije bolesnika liječenih transplantacijom matičnih stanica}

U zadnjih deset do petnaest godina klinička su istraživanja pokazala važnost preventivnoga i individualnoga rada u unapređenju kvalitete života prije i poslije transplantacije matičnih stanica. Transplantacija matičnih stanica ima znatan negativan utjecaj na bolesnikove svakodnevne aktivnosti i na integraciju u zajednicu. Transplantirane su osobe često u znatnoj mjeri kraće ili duže vrijeme onesposobljene za obavljanje fizičkih aktivnosti i društvenih funkcija. Predtransplantacijska fizikalna terapija može značajno utjecati na kvalitetu njihova svakodnevnoga života. Prije i nakon TKMS-a javlja se širok opseg muskoloskeletnih komplikacija te je zbog toga potrebno što prije početi s ranom fizioterapijom kod bolesnika sa HSCT-om. Važnost fizioterapije na odjelima za transplantaciju prvenstveno se ogleda u sprečavanju komplikacija dugotrajnoga ležanja (Wiskemann, 2008: 321).

Tjelesna aktivnost nakon TKMS-a osjetno pada u odnosu na tjelesnu aktivnost prije transplantacije. Rehabilitacija će neposredno nakon transplantacije uključivati održavanje postojećih funkcija, smanjenje simptoma, održavanje postojeće mišićne mase i snage, smanjenje rizika od upale pluća, atelektaze te poboljšanje aerobnoga kapaciteta. U posttransplantacijskoj rehabilitaciji vježbanje se pokazalo poželjno zbog toga što može utjecati na preživljavanje bolesnika. Istraživanje je pokazalo da kreirani 
programi za svakoga pojedinca mogu učinkovito održati aktivnost bolesnika (Wiskemann, 2008: 321).

Danas još ne postoje jasne zadane zdravstvene smjernice za fizioterapiju u bolesnika tijekom i nakon liječenja TKMS-om te se zbog toga još provode studije i istraživanja koja bi mogla dati jasne smjernice u rehabilitaciji ovih bolesnika (Mohammed et al., 2019: 127). Izazov je identificirati i integrirati rehabilitaciju u bolničkom i izvanbolničkom okruženju. Bolnički pristup rehabilitaciji podijeljen je na predtransplantacijski i posttransplantacijski pristup.

\subsection{Predtransplantacijska fizioterapija}

Znatan broj bolesnika ima izniman pad aktivnosti prije početka TMK-a zbog velikoga broja kemoterapija, zračenja, kirurških zahvata te medicinskih komplikacija. Predtransplantacijska je rehabilitacija iznimno važna jer ranim djelovanjem možemo minimalizirati kasnije teže komplikacije i gubitak funkcionalnosti. Teoretski gledano, poboljšavanje mišićne snage i kardiorespiratorne rezerve može imati znatan utjecaj na tijek i sihod liječenja transplatacijom. Predtransplantacijska rehabilitacija ima cilj pripremiti bolesnika poboljšanjem respiratornoga volumena, zadržavanjem opsega pokreta (ROM) i sprječavanjem komplikacija dugotrajnoga ležanja (Mohammed et al., 2019: 127).

\subsubsection{Individualna medicinska gimnastika}

Najvažnije komponente medicinske gimnastike jesu individualno vođenje i prilagodba bolesniku. Individualna medicinska gimnastika uključuje nekoliko tipova vježbi. Vježbe opsega pokreta neke su od najvažnijih vježbi u predtransplantacijskoj fizioterapiji, a mogu se podijeliti na aktivne, pasivne i aktivno potpomognute. Vježbe obično započinju voljnim/aktivnim pokretom - bolesnik izvodi samostalne kretnje do krajnje mogućnosti opsega pokreta, a uz potporu fizioterapeuta bolesnik povećava opseg pokreta u zglobu. Ciljanim vježbama individualne medicinske gimnastike doći će do smanjenja boli, povećanja opsega pokreta i fleksibilnosti. Vježbe se provode u trajanju od 15 minuta do jednoga sata ovisno o bolesnikovu stanju (Mortimer, 2010: 1331).

\subsubsection{Vježbe za poboljšanje aerobnoga sustava}

Za poboljšanje aerobnoga kapaciteta, ali i održavanje svakodnevne aktivnosti bolesnika najbolje se pokazalo brzo hodanje. Smatra se da je brzo hodanje svako hodanje koje prelazi brzinu od $5 \mathrm{~km} / \mathrm{sat}$ do $8 \mathrm{~km} / \mathrm{sat}$. Redovitim brzim hodanjem bolesnik povećava respiratorni volumen, održava tlak u normalnim vrijednostima te jača srčani mišić što nam daje idealnu podlogu za prevenciju razvoja mogućih komplikacija ležanja. Aerobne vježbe koje se preporučuju svakako su hodanje, koračanje, vožnja bicikla, ergometar te traka za hodanje. Za poboljšanje aerobnoga kapaciteta u bolničkom 
okruženju fizioterapeut se može poslužiti nekim od testova kao što su šestominutni test i timed up and go test, a pritom dobiti i podatke o bolesnikovu aerobnom statusu. U aerobnu rehabilitaciju iznimno je bitno uključiti i vježbe disanja (Bobinac, 2010).

\subsection{Posttransplantacijska fizioterapija}

U posttransplantacijskom periodu fizioterapijska intervencija može se temeljiti na funkcionalnim vježbama, tj. vježbama snaženja/izdržljivosti, propriocepciji/ravnoteži i aerobnim vježbama (tablica 3) (Wiskemann, 2008: 321). Fizioterapeut svoj plan i program rehabilitacijskoga tijeka treba donijeti u suglasnosti s rehabilitacijskim timom. Rehabilitacija bolesnika trebala bi slijediti SMART, tj. specifičan (engl. specific), mjerljiv (engl. measurable), ostvariv (engl. achieveable), razuman (engl. reasonable) i vremenski ograničen (engl. time limited). Velik broj bolesnika teži ka funkcionalnom napretku, odnosno povratku na posao ili u sportske aktivnosti, što će uz SMART zauzimati dodatne ciljeve (ciljevi obitelji, ciljevi pacijenta, ciljevi uže i šire društvene zajednice) te pažljivo planiranje fizioterapijskih postupaka. Fizioterapeut treba svaku intervenciju osmišljeno i planski provesti te priopćiti rehabilitacijskom timu zbog mogućih novonastalih promjena, kao posljedice GVHD-a koji se može manifestirati na MSK sustavu. Zbog mogućih nuspojava nakon transplantacije fizioterapeut bi trebao provoditi procjenu MSK sustava i kardiorespiratornoga sustava s ciljem otkrivanja i sprječavanja dugotrajnih komplikacija. Međutim, da bi se promjene uočile pravovremeno, funkcionalnu bi procjenu trebalo provoditi četiri tjedna, osam tjedana, 12 tjedana, 15 tjedana, 18 tjedana i 21 tjedan nakon transplantacije (Mohammed et al., 2019: 127).

Tablica 3. Mogući intenzitet vježbanja u bolenika liječenih transplantacijom krvotvornih matičnih stanica (HSCT - haematopoietic stem cell transplantation)

$\begin{array}{cl}\text { Faze terapije } & \\ \text { prije HSCT } & \text { mješovita vježba (3-5 puta tjedno) } \\ & \text { trajanje (sesija): do } 30 \text { min } \\ & \text { intenzitet: umjeren (Borgova skala 12-14, 70-80\% maksimalnog HR) } \\ & \text { trening izdržljivosti (5 puta tjedno), počevši s treningom otpora ako je } \\ & \text { došlo do povećanja broja trombocita u zadnjoj trećini hospitalizacije } \\ & \text { (2-3 puta na tjedan) } \\ \text { tijekom HSCT-a } & \text { trajanje (sesija): 10-15 min na početku (ako je korisno koristiti intervalnu } \\ & \text { metodu), do 30 min na kraju } \\ & \text { intenzitet: umjeren (Borgova skala 12-14, 70-80\% maksimalnog HR) } \\ & \text { mješovito vježbanje (3-5 puta tjedno) } \\ & \text { trajanje (sesija): do 30 min i više } \\ & \text { intenzitet: umjeren (Borgova skala 12-14, 70-80\% maksimalnog HR) }\end{array}$

Izvor: Wiskemann, 2008: 321 
Pod funkcionalnom procjenom podrazumijevamo inspekciju, palpaciju, perkusiju, procjenu funkcionalnoga statusa pacijenta, MMT, ROM (mjere opsega pokreta ruku i nogu), askulutaciju, mobilnost prsnoga koša (aksilarno, mamilarno, bazalno), mjerenje opsega ruku i nogu, mjerenje dužine ruke i noge te indeks tjelesne mase.

Fizioterapeut treba biti usmjeren na prevenciju i rehabilitaciju ciljanih i specifičnih oštećenja u bolesnika sa HSCT-om. Usmjerenost na oštećenja koja proizlaze iz liječenja transplantacijom kao što su avaskularna nekroza, osteoporoza, osteopenija, promjene u sklopu akutnog i kroničnog GvHD-a te druga oštećenja znatno će ublažiti njihov utjecaj na fizičko i psihičko stanje bolesnika. Stoga je važna primjena fizioterapije i prije same transplantacije kako bi se prevenirale moguće promjene na lokomotornom i kardiorespiratornom sustavu, a posttransplantacijska fizioterapija veoma je važna za bolesnika zbog lakšega povratka u svakodnevne aktivnosti. U tablici 3 prikazan je preporučeni intenzitet vježbanja u pojedinim fazama liječenja transplantacijom.

\subsection{Utjecaj broja trombocita i razine hemoglobina na provođenje fizikalne terapije}

Nizak se broj trombocita (manji od $20 \times 10^{9} / \mathrm{L}$ ) u prošlosti, a i danas, smatrao kontraindikacijom za vježbanje s obzirom na povećanu sklonost krvarenju pri niskom broju trombocita. Ipak, većina bolesnika liječenih TKMS-om sposobna je tolerirati vježbanje te imati pozitivne učinke od vježbanja unatoč malom broju trombocita (manje od 10 000/mcL) (Mohammed et al., 2019: 127).

Mogući intenzitet vježbanja u odnosu na broj trombocita prikazan je u tablici 4. Fizioterapeut bi trebao uzeti u obzir cijelu kliničku sliku i opće stanje bolesnika te sukladno tomu odlučiti može li bolesnik odraditi vježbe. Transfuzija trombocita ili krvnih pripravaka preporučuje se prije fizioterapijskoga vježbanja u bolesnika koji imaju broj trombocita i hemoglobina manji od $10 \times 10^{9} / \mathrm{L}$, odnosno $80 \mathrm{~g} / \mathrm{L}$ (Mohammed et al., 2019: 127). Svi koji imaju razinu hemoglobina nižu od $80 \mathrm{~g} / \mathrm{L}$ ne bi trebali sudjelovati u fizioterapijskom vježbanju (Mohammed et al., 2019: 127).

Tablica 4. Intenzitet vježbanja u odnosu na broj trombocita

\begin{tabular}{|cc}
\hline Broj trombocita & Intezitet vježbanja \\
\hline $5000 \times 10^{9} / \mathrm{L}$ & Vrlo lagani \\
\hline $5000-20000 \times 10^{9} / \mathrm{L}$ & Lagani do umjereni \\
\hline $21000-30000 \times 10^{9} / \mathrm{L}$ & Umjereni \\
\hline $31000-50000 \times 10^{\circ} / \mathrm{L}$ & Umjereni do intenzivni \\
\hline
\end{tabular}




\section{Značenje fizioterapije u liječenju bolesnika transplantacijom krvotvornih matičnih stanica}

Fizioterapijska je struka značajna za širok spektar bolesnika, pa tako i za hematološkoga bolesnika, a posebno onoga liječenoga TKMS-om s obzirom na intenzitet terapije te težinu komplikacija koje prate liječenje transplantacijom. Unatoč tome što je fizioterapija potrebna kod hematoloških bolesnika, nedovoljno je istražena. Fizioterapija kod hematološkoga bolesnika iznimno je složena, ali je provediva uz dobro planiranje i organizaciju. Da bi fizioterapija kod hematološkoga bolesnika bila adekvatna, treba uključiti više segmenata fizioterapije. Iznimnu važnost treba pridati fizioterapijskoj procjeni prije samog TKMS-a i u posttransplantacijskoj rehabilitaciji. Fizioterapeutov je cilj uočiti prijašnje deformacije na muskoloskeletnom sustavu te novonastale promjene na bolesniku. Fizioterapeutov cilj u predtransplantacijskoj rehabilitaciji jest provođenje vježbi kojima će umanjiti ili u potpunosti izbjeći komplikacije koje nastaju uslijed dugotrajnoga ležanja (upala pluća, dekubitus, dispneja). Posttransplantacijska fizioterapija trebala bi se usmjeriti na prevenciju promjena lokomotornoga (osteoporoza, osteopenija) i kardiorespiratornoga sustava. U fizikalnoj se rehabilitaciji pacijenata sve veći naglasak stavlja također i na smanjenje upale koja izaziva umor i utječe na aktivnost bolesnika.

Fizikalna je terapija nedvojbeno korisna i pridonosi oporavku pacijenata. Bolesnici s hematološkim oboljenjima izloženi su nekim čimbenicima rizika tijekom fizikalnih terapija. Stoga fizioterapeuti trebaju obratiti pozornost i upravljati čimbenicima rizika. Fizioterapeuti moraju biti svjesni da oboljeli od raka imaju značajan pad aktivnosti zbog umora i bolova istovremeno, zato fizikalna terapija može imati važnu ulogu u poboljšanju fizičke funkcije, psihološke funkcije te kvalitete života bolesnika.

\section{Literatura}

1. Baumann, F. T., Kraut, L., Schule, K., Bloch, W. i Fauser, A. A. 2010. A controlled randomized study examining the effects of exercise therapy on patients undergoing haematopoietic stem cell transplantation. Bone Marrow Transplantation, 45 (2): 355-62.

2. Bergenthal, N., Willi, A., Streckmann, F., Wolkewitz, K. D., Monsef, I., Engert, A. et al. 2014. Cochrane Library, Aerobic physical exercise for adult patients with haematological malignancies Cochrane Database Syst Rev, Nov 11.

3. Bhavaraju-Sanka, R. i Jackson, C. E. 2014. Cushing's Syndrme and Steroid Myopathy, u: Encyclopedia of the Neurological Sciences (Second Edition). [Internet, 17. travnja 2020.].

4. Bobinac, D. 2010. Osteoporoza i vitamin D. Zadar: Edicija magna.

5. Coleman, E. A., Coon, S., Hall-Barrow, J., Richards, K., Gaylor, D. i Stewart, B. 2003. Feasibility of exercise during treatment for multiple myeloma. Cancer Nursing, 26 (5): 410-19.

6. Čustović, F., Goldner, V., Čikeš, I. et al. 1995. Klinička kardologija. Promjene kardiovaskularnog sustava u hematoloških bolesnika. Zagreb: Medicinska naklada. 
7. DeFor, T. E., Burns, L. J., Gold, E. M. i Weisdorf, D. J. 2007. A randomized trial of the effect of a walking regimen on the functional status of 100 adult allogeneic donor hematopoietic cell transplant patients. Biology of Blood and Marrow Transplantation, 13 (8): 948-55.

8. Labar, B. 2008. Transplantacija krvotvornih matičnih stanica, u: Vrhovac, B. et al., Interna medicina. Naklada Ljevak. Zagreb: 1091-1094.

9. Mohammed, J. et al. 2019. Physical therapy pathway and protocol for patients undergoing hematopoietic stem cell transplantation: Recommendations from The Eastern Mediterranean Blod and Marrow Transplantation (EMBMT) Group. Hematol Oncol Stem Cell Ther, 12: 127-132.

10. Mortimer, J. E. et al. 2010. Studying Cancer-Related Fatigue: Report of the NCCN Scientific Research Committee. December. 1331-1339.

11. Steinberg, A., Asher, A., Bailey, C. i Fu, J. B. 2015. The role of physical rehabilitation in stem cell transplantation patients. Support Care Cancer, 23 (8): 2447-2460.

12. Wiskemann, J. i Huber, G. 2008. Physical exercise as adjuvant therapy for patients undergoing hematopoietic stem call transplantation. Bone Marrow Transplantation, 41: 321-329.

\title{
Physiotherapy in haematopoietic stem cell transplantation
}

\begin{abstract}
Physiotherapy has its place in almost all branches of medicine, even as part of the treatment of patients with malignant diseases. This paper discusses the role of physiotherapy in patients with hematological malignancies treated with hematopoietic stem cell transplantation. The course of treatment with hematopoietic stem cell transplantation from the preparation for transplantation to the period after transplantation and the problems and complications that occur are presented. Transplantation treatment was accompanied by a number of complications such as changes in the musculoskeletal system and in the cardiovascular and respiratory systems. The problem of acute and chronic graft-versus-host disease (GvHD) is particularly pronounced. The treatment to which the patient is subjected and consecutive complications result in a variety of serious physical changes that affect the physical condition, quality of life of the patient and the final outcome of treatment. Physiotherapy of these patients is extremely important at all times of treatment, and its effects on the quality of life of patients, reduction of complications, and the final outcome of treatment are relatively poorly investigated. Due to the specific condition and complications after transplantation, hematological patients need a unique and complex approach in physiotherapy procedures. However, there are no clear guidelines and protocols that physiotherapists would necessarily follow and implement in patients treated with hematopoietic stem cell transplantation. Previous experiences are described and possible approaches to physiotherapy of these patients are listed.
\end{abstract}

Key words: hematological patient, hematopoietic stem cell transplantation, quality of life, physiotherapy intervention 